\title{
Deficiencies in Project Governance: An Analysis of Infrastructure Development Program
}

\author{
Asadullah Khan ${ }^{1, *(1)}$, Muhammad Waris ${ }^{1, *}$, Ishak Ismail ${ }^{1}$, Mirza Rizwan Sajid ${ }^{2}$, \\ Mehfooz Ullah ${ }^{1}$ and Faisal Usman ${ }^{3}$ \\ 1 Faculty of Industrial Management, Universiti Malaysia Pahang, Gambang, Pahang 26600, Malaysia; \\ ishakismail@ump.edu.my (I.I.); mehfoozullah@kiu.edu.pk (M.U.) \\ 2 Faculty of Industrial Science and Technology, Universiti Malaysia Pahang, Pahang 26000, Malaysia; \\ mirzarizwansajid@gmail.com \\ 3 Planning \& Development Department, Government of Gilgit-Baltistan, Gilgit 15100, Pakistan; \\ faysalosman@gmail.com \\ * Correspondence: asad@kiu.edu.pk (A.K.); waris@ump.edu.my (M.W.)
}

Received: 30 November 2018; Accepted: 10 January 2019; Published: 11 January 2019

\begin{abstract}
The governance of public sector infrastructure projects became an important topic of interest in the project, program, and portfolio management literature during the last decade. Today, it is becoming a central focus for policymakers seeking to ensure success in selecting, designing, and implementing government-sponsored programs of multi-projects. Due to the multiple underlying risks and complexities, the governance of infrastructure programs constitutes a critical element in strategic planning in developing countries. This paper has analyzed the infrastructure development program in Gilgit-Baltistan (Northern Pakistan), and revealed major shortcomings in the areas of decision-making, stakeholder management, and role ambiguity. Approaches to remedy these shortcomings have, thus, been proposed.
\end{abstract}

Keywords: project governance; program; infrastructure development; Gilgit-Baltistan

\section{Introduction}

The term 'governance' is derived from the Greek verb "Kubernao", which means "to steer". It is the "act of governing or directing the policies, management, and activities of an organization at the highest level, with the authority, credibility, and responsibility to do so" (Kanyane and Sausi 2015). The concept of governance has been reviewed by many scholars in a variety of meanings and interpretations. Nevertheless, their focal point remains with the socio-economic interactions of processes in various public and private entities. According to Rhodes (1996), governance has its multifaceted roles in the operation of governmental organizations and it is mainly triggered by independent decision making in associated networks to perform and deliver public services. Furthermore, Stoker (1998) also argued that governance is primarily concerned with the steering mechanism to facilitate state functions for the provision of services. Governance structures and processes define and create sub-systems for operating procedures and are devised to ensure the common direction of the distributed effort (Schroeder et al. 2012). Meso et al. (2009) have further emphasized that governance raises issues associated with economic and social responsibilities and collective actions for power dependence among related institutions. In an international context, governance means the ways in which legitimate authority is used to cope with the country's social and economic resources for development (Meso et al. 2006).

In contemporary project management literature, the governance has become an important topic for discussion, and organizations have used this approach to meet organizational goals and objectives. Organizations initiate projects with the best of intentions to succeed, but due to governing and 
managing issues, many projects fail, and the reasons are often unclear. Traditionally, the outcomes of projects have been measured in terms of completing them within the constraints of scope, time, cost, and quality (PMI 2013). However, increasingly, assessments of projects are being expanded to governance, to include their ability to achieve strategic goals over considerable periods of time (PMI 2016). An attribute of good governance is that it has the aptness to navigate the projects through different uncertainties and unexpected events (Miller and Floricel 2000). Garvin (2009) has stressed the motivation of stakeholders for project goals towards achieving good governance. Levitt et al. (2009a) have discussed the ownership and commitment of the project's sponsor, in regard to the project executor in long-term infrastructure development projects.

Effective governance is also imperative for public-private infrastructure development projects (Reside and Mendoza 2010). Thus, failure of such large capital projects has highlighted the consequences of ineffective governance (Flyvbjerg et al. 2003). Furthermore, Guo et al. (2014) have stated that in infrastructure projects, complexities and uncertainties are very common and the distinctiveness and individuality of infrastructure projects arise from their unique social and environmental requirements. Infrastructural needs are critical for the economic growth of developing countries. To achieve this, the effective governance of the infrastructure development projects has become a certain need and significant challenge, which defines the success of these projects. In a nutshell, governance is a function for developing strategies, overseeing needs and objectives, making decisions concerning projects, and following up on performance across the organization.

Precedent scholars have addressed the need for better project performance in the public sector infrastructure in Pakistan (Irfan and Hassan 2017; Khattak et al. 2016; Unab and Kundi 2014; Noor et al. 2013). Their studies show that the theme of project governance has not been addressed in detail in the context of Gilgit-Baltistan. This research gap was a main objective for identifying the governance issues in the public sector infrastructure development program in Gilgit-Baltistan. The review paper will provide a future direction for effective planning, and policy formulation of provisional government departments of Gilgit-Baltistan.

\section{Related Work on Project Governance}

McGrath and Whitty (2015) have described project governance as "the system by which a project is governed, directed, and controlled". Project governance is involved in management and governance functions for individual projects and their deliverables (Too and Weaver 2014). Bekker and Steyn (2007) have identified that "project governance is a set of management systems, rules, protocols, relationships, and structures that provide the framework within which decisions are made for project development and implementation to achieve the intended business or strategic motivation". So, project governance can support a good operational environment and provide a guarantee for project success. In the early stages, neither the plans nor the formal contracts to govern the actions and relationships of the parties are involved, but there is still a belief that some kind of governing processes is at play (Hellström et al. 2013).

The academic-research perspective has also befitted that governance is an important concern of sponsors for mega investments, and subsequently, it affects the project outcomes (Sharma 2012). Project governance is considered a critical success factor in project execution (Garland 2009). Later, this argument was also supported by Pinto (2014), who stated that governance of projects provides the structure to execute the projects, thus resulting in an increase in the probability of project success. Furthermore, (Levitt et al. 2009b) identified two different types of challenges in infrastructure project governance, which appear during the project initiation, implementation, and operational phases. The first is "opportunism in the presence of displaced agency-i.e., conflicts between the incentives of the parties leading the decision-making in each of the successive and interdependent phases of design, construction, and operations that lead to sub-optimal investment and may lead them to pursuing their self-interest with guile. The second is a political and regulatory risk-i.e., ex-post political interventions in operational decisions". According to Zhai et al. (2009), key features of mega infrastructure projects 
include longer life cycles, uncertainty, complications, and a large number of stakeholders, as well as their effect on the economy, community, technological development, and the environment.

Jonny Klakegg (2009) has argued that the presence of governmental stakeholders may create further political uncertainties for the project. The project governance prerequisite is to explore how resources and risks are to be assigned among stakeholders to define the control measures for achieving the targeted objectives, which are defined by legal and regulatory mechanisms, with the aim of ensuring better utilization of public funds (Klakegg et al. 2007). There are several cases where big infrastructure projects provide common examples of cost overruns due to unique site conditions, delays, hidden costs, and conflicts among the groups (Ogunlana 2010; Khan et al. 2018). Guo et al. (2014) have suggested that empirical studies of management systems in large infrastructure projects have designed appropriate forms of governance for managing risks to better understand existing circumstances. There are two features of infrastructural development projects which have made them ideal for understanding socio-political governance. Firstly, the infrastructure projects are produced by multiple counterparties through a complicated series of interlinked transactions, and secondly, the significance with respect to catalytic functions in the development process and national security and comfort has made the infrastructure development process politically salient (Levitt et al. 2009a). China's socio-economic and environmental conflicts in public infrastructure and construction (PIC) projects are handled through public participation (Xie et al. 2014). Participation is a process through which stakeholders motivate and share control over priority-setting, policy-making, resource allocation, and access to public goods and services (World Bank 2017).

The conceptualization of project governance has been driven from a "project management" point of view, and the majority of authors on project governance, who are from the project management background, are attempting to construct a project governance framework through a bottom-up approach (Bekker 2015). Abednego and Ogunlana (2006) have advocated for the integration of concepts pertaining to good project governance and the project management approach. They have further proposed the characteristics of good project governance, which are as follows:

a. Active participation, which is the right decision at the right time;

b. Contract fairness, meaning a rule of law to be enforced impartially;

c. Transparency, where information must be freely available and implementation of the decisions must be according to the rules and regulations;

d. Responsive decisions made must be implemented within a stipulated time period;

e. Project monitoring and control in order to achieve strategic goals to meet and exceed the satisfaction of all the stakeholders;

f. Equality between all involved parties, where all parties have the same opportunities to improve and maintain their own well-being;

g. Effectiveness and efficiency through optimal utilization of resources and through sustainable utilization of natural resources; and;

h. Accountability must be enforced through rule of law and transparency and should be in the form of public participation and user satisfaction.

Garland (2009) identified four key principles to achieve these characteristics and to ensure good governance, where the correct person holds the correct position. These principles are: identification of single point accountability, explicitly; service delivery focus of project governance; separation of project governance from organizational governance; and the separation of stakeholder management from project decision-making (Garland 2009). The identification of single point accountability safeguards the clarity and timeliness of the decision-making. Service delivery focus and ownership regulate project ownership. Separating the stakeholder management from the decision-making activities will prevent ineffective decision-making and the possible chokehold between the decision-making bodies and the stakeholders. Separating the structure of project governance from organizational governance 
will decrease the number of project decision layers, as the project decision path will not be mingling with the organizational line of command.

Furthermore, the overall success of the project delivery can be achieved through the synchronization and control of the processes, engaging all the stakeholders and resolving their conflicts of interest, and also by recognizing the value of the project and forming a link between the stakeholders in light of their rights, responsibilities, and interests.

Narayanan and DeFillippi (2012) have characterized five elements which are incorporated in the structure-based governance: stage gate approval process, stakeholder representation, formal roles and responsibilities, quality assurance, and contracts and sign-offs. Each one of these elements can reveal disparities across organizations and among project classes within the same organization. Relationship-based governance typically focusses on non-hierarchical elements, such as leadership, motivation, incentives, resource allocation, alliances, stakeholder's engagement, informal relations, and communication. Patanakul et al. (2016) have recommended that managerial focus on stakeholder engagement can enhance the project performance of public sector projects. According to Hjelmbrekke et al. (2017), governance is basically about leadership selection, incentives, control systems, and monitoring.

Müller et al. (2017) have also recommended standardized approaches to project governance for successful completion of the project and the project-based part of the organizations. By the augmented use of project governance from a strategic perspective, the efforts for aligning project outputs to a general strategy can be easily secured (Hjelmbrekke et al. 2017).

The Transaction Cost Economics (TCE) theory is also a well-known theoretical perspective in project governance (Ahola et al. 2014). According to the TCE theory, every economic exchange has a cost (i.e., a "transaction cost"), and the organizations act to minimize these costs (Williamson 1979). This theory has some resemblances with agency theory, as both theories seek to curtail opportunism and self-interest through governance mechanisms (Kochhar 1996). However, TCE theory puts an emphasis on individual transactions, whereas the focus of agency theory is on the principal-agent relationship. In the project governance context, the TCE theory may be applied to define the process of selecting contractors and suppliers (Winch 2001).

Table 1 has summarized the findings of contemporary researchers with a specific focus on the project governance mechanism, issues, and its indispensable role in delivering mega projects. The findings show that the unsatisfactory performance and failure of large-scale government projects are due to the missing governing surveillance of vague project outcomes, intricate nature of stakeholders, weak project governance mechanism, multi-layered organizational structure, and ineffective management control. Beside these, as governments are vital stakeholders for development projects, often their roles are as owners or initiators. The finding shows that project governance helps in aligning the project output to the strategy of the organization, which will help in enhancing the project performance. 
Table 1. Summarized findings on the role of project governance.

\begin{tabular}{|c|c|c|}
\hline Sources & Focus of Study & Key investigations and Findings \\
\hline (Zhai et al. 2017) & Governmental governance of mega projects & $\begin{array}{l}\text { Encouraging accountability of the project leaders. } \\
\text { Supporting cultural control. }\end{array}$ \\
\hline (Cardenas et al. 2017) & Project governance of infrastructure projects & $\begin{array}{l}\text { Project governance model for infrastructure projects. } \\
\text { The model considers the project governance aspects, i.e., involvement of the } \\
\text { contractor in the design and estimation of costs, procurement procedures, } \\
\text { integration of the design and construction, the incentive and disincentive } \\
\text { regimes, risk allocation, contract flexibility, and actions that allow the } \\
\text { contracting party to maintain bargaining power during possible renegotiations. }\end{array}$ \\
\hline (Müller et al. 2017) & Governance and governmentality of projects & $\begin{array}{l}\text { Governance is a structural context, within which governmentality is } \\
\text { implemented. } \\
\text { Governance moderates the governmentality's impact on the success. } \\
\text { Successful projects tend to use standardized combinations of governance } \\
\text { approaches. }\end{array}$ \\
\hline (Hjelmbrekke et al. 2017) & $\begin{array}{l}\text { Project governance as value addition in building } \\
\text { projects }\end{array}$ & $\begin{array}{l}\text { Aligning project output to the strategy of the organization. } \\
\text { Governance is primarily about monitoring, leadership selection, incentives, } \\
\text { and control systems. }\end{array}$ \\
\hline (Brunet and Aubry 2016) & Governance framework for major public projects & $\begin{array}{l}\text { There are three propositions on the governance dimensions, i.e., efficiency, } \\
\text { legitimacy and accountability. }\end{array}$ \\
\hline (Macheridis 2017) & Implementation of project governance & $\begin{array}{l}\text { Processes and structures to govern multiple projects and to manage strategic } \\
\text { objectives. }\end{array}$ \\
\hline (Zwikael and Smyrk 2015) & $\begin{array}{l}\text { Project governance-balancing control and trust in } \\
\text { dealing with risk }\end{array}$ & $\begin{array}{l}\text { Ethical decision-making and managerial action within an organization that is } \\
\text { based on transparency, accountability, and defined roles. }\end{array}$ \\
\hline (Xiang et al. 2013) & Critical Success Factors of Project Governance in China & $\begin{array}{l}\text { Project governance is a framework for decision-making, including a series of } \\
\text { structures, systems and processes, rules, and methods to support and } \\
\text { complement the functional goals of project management. }\end{array}$ \\
\hline
\end{tabular}




\section{Need of Project Governance for Infrastructural Planning in Pakistan}

In Pakistan, growth in the infrastructure sector is vital, as it is among the leading sectors which generate business opportunities. This sector is important for economic development and an imperative key driver for the country's economic growth (Azhar et al. 2008). It is also one of the potential sectors which provide massive employment opportunities for skilled and semi-skilled laborers (Azhar et al. 2008). The need of infrastructure projects is growing at an enhanced pace in Pakistan, however, the available financial resources of the country are not matching the demand for implementation. It is not merely because of the limited fiscal space, but also because there is a severe lack of capacity in public-sector organizations to deliver better performance (Noor et al. 2012). Despite this fact, it has been witnessed that not much consideration has been paid by the government for handling the problems associated with this sector. In developing economies, the "planning" and "managing" of public sector infrastructure projects have been known as two of the leading dilemmas. Infrastructure projects in developing countries are more likely to be affected by unstable political and economic environments (Lizarralde et al. 2008).

Since its independence, Pakistan has been plagued with extensive poverty and ineffective governance structures. Due to unstable political system, government sponsored project performance has been in a declining trend for many years (Ahmed and Mohamad 2014). Addressing the infrastructural needs, especially in view of the current economic scenario of Pakistan, government agencies and construction industry stakeholders have to explore more efficient and effective ways of delivering projects (Noor et al. 2012). Therefore, this study has proposed project governance as an essential strategy for attaining better project performance in the public sector infrastructure projects of Gilgit-Baltistan.

\section{Method}

\subsection{Description of the Case Study Area}

Gilgit-Baltistan is located in the northern region of Pakistan, at the confluence of three gigantic mountain ranges - the Karakoram, Hindukush, and Himalaya ranges—and shares its borders with China, Afghanistan, and India. The famous Karakoram Highway connects Gilgit-Baltistan with China's Xinjiang Uyghur region and traces one of the many paths of the ancient Silk Road. The territory became a distinct administrative unit of Pakistan in 1970 under the name "Federally Administered Northern Areas". It was formed by the amalgamation of the Gilgit Agency, Baltistan, and the states of Hunza-Nagar (Burki 2015). Since then, the region has been administratively controlled by the Government of Pakistan without being formally integrated or fully participating in Pakistan's constitutional and political affairs. In 2009, the federal government implemented legislative reforms entitled the "Gilgit-Baltistan Empowerment and Self-Governance Order", which granted self-autonomy to the native people by establishing an elected legislative assembly and council. With this governmental transformation, Gilgit-Baltistan acquired the status of a de-facto province, having three divisions and ten districts, and occupying an area of $72,971 \mathrm{Km}^{2}$ (Kazim et al. 2015). These new reforms in the Gilgit-Baltistan government have provided autonomy in terms of the administration, regulation, governance, and functioning of the government departments.

In Gilgit-Baltistan, all of the development project planning is being carried out through the Planning and Development (P and D) Department. The main function of this department is the formulation of the provincial government vision, policies and strategies for economic planning, and development in consultation with all the stakeholders. It is also responsible for the development of the appropriate cost and physical standards for the effective technical and economic appraisal of the projects (Haider et al. 2014). The preparation of the annual development plan is an important exercise carried out by the P and D Department, in collaboration with the Finance Department and other provincial departments. These exercises are based on the guidelines provided by the Planning Commission and the federal government in accordance with national priorities and resource 
availability (PC 2010). The monitoring section of the P and D Department looks into the financial and physical progress and probes the outcomes and impacts of the development programs.

Over the last decade, the government has initiated a program of economic transformation that undertakes mega projects with the help of foreign direct investment. In this regard, most of the projects were found to be problematic, inefficient, high time consumption, and suffer cost overruns. Beside this, none of the projects had met its desired objectives. Table A1 in Appendix A has summarized these 126 public sector infrastructure projects chosen for the analysis.

\subsection{Case Study}

We followed the case study methodology because the research was exploratory in nature and the previous research on the project governance of infrastructure projects was also limited. To study a contemporary phenomenon, and the how and why of the research questions, case studies had been considered suitable (Yin 2017). Also, case studies have been used as a tool for the preliminary, exploratory stage of a research project (Rowley 2002). We began by conducting an in-depth review of the prior scholarly works addressing the management and governance of large-scale infrastructure projects. In order to gain an understanding of the study's empirical context, we gathered archival and document-based data, including government planning manuals, a master development plan, appraisal reports, contract documents, monitoring documents, and evaluation reports. The collected documents were the primary data for project governance, and they were analyzed and categorized under the aspect of project governance issues. The interpretative approach was used for the review process, which offered an inclusive summary of the topic area (Grant and Booth 2009). The data were thematically evaluated to classify and report the hidden and apparent patterns in the content (Vaismoradi et al. 2013).

\subsection{Extraction of Data}

There were two main sources of data, as discussed earlier in this section;

1. Literature review

2. Official published reports and documents

The literature had been searched with different phrases like: "project governance issues", "failure in project governance", "lack of project governance as reasons of project failure", "issues in public infrastructure projects", etc., from Scopus, Web of Science, Google scholar, SSRN, etc. Then, the selected articles underwent the process of screening, which defined their relevancy about the selection. Only those articles which followed the given criteria were chosen;

1. Published in the time span of 2009 to 2018

2. Focused on the public infrastructure projects

After the finalization of the articles, as per the criteria mentioned above, the main issues in project governance were highlighted. The list of issues was the global point of view about project governance. This list was augmented with a local context as well, by adding the information extracted from the second source of information about project governance in this study, which was officially published documents. Usually, every project report concludes with the issues and limitations which the project teams had to face during the execution of the projects. From these sections, we searched the information about the issues in project governance and its related problems. We performed a thematic analysis of the retrieved information. It was found that $80 \%$ of the retrieved key issues in project governance were matched with a global point of view, finalized at an earlier stage of the data retrieval.

A summary was formed from the categorized documents. This primary analysis was used to develop an outline for the interviews. Interviews with twenty-five key officials of the Planning and Development department were carried out. The average duration of the interviews was about one hour. The interviewees were chosen on the basis of their expertise and central role in the project. 
The respondents had an average of 20 years of experience in the public sector (ranging from 10 to 30). The interview outline was developed based on the literature review and the initial findings of the document analysis. The topics outlined in the interviews were related to project governance issues in public sector infrastructure projects. The approach enabled the interviewees to share their experiences and opinions openly and broadly. Key points were noted during the interviews. The interviews were analyzed through the ordinary thematic approach. While writing up the results, we verified and compared the document-based data and the interviews repeatedly, as a means of data triangulation. Figure 1 illustrates the process flow for the identification of governance issues of this research.

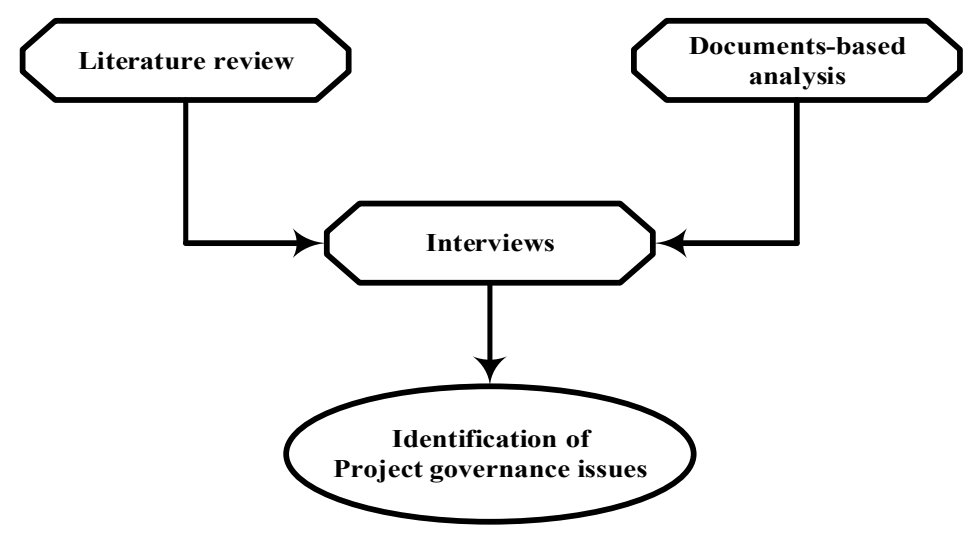

Figure 1. Research process.

\section{Results and Analysis}

In this study, we explored and identified project governance issues in the public sector infrastructure projects of Gilgit-Baltistan, as depicted in Figure 2. It is based on the information of twenty-five interviews. The details of the ten identified project governance issues during the interview sessions are described below:

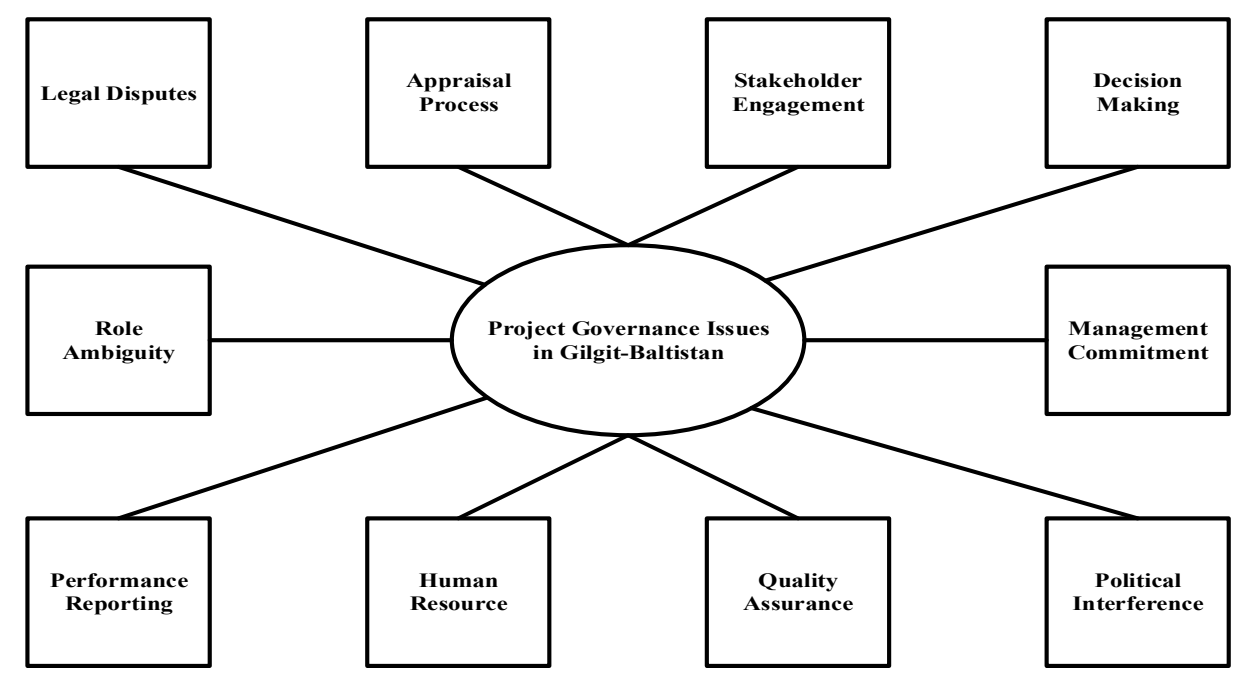

Figure 2. Project Governance Issues in Gilgit-Baltistan.

\subsection{Appraisal Process}

In the appraisal phase, the project needs are addressed and realistic alternatives for meeting these prerequisites are identified and assessed for their efficiency and effectiveness. Traditionally, a project charter is prepared to cover the specific business plan, risk analysis, and budget constraints. The outcome of the appraisal phase is a formal document known as the "Project Feasibility Study". Later on, it is presented for administrative and management approvals. Moreover, the appraisal process 
not only establishes the boundaries of the project's triple constraints (i.e., time, cost, and quality) and gives team members a three-dimensional limit where they have to work on the project, but it also helps the clients to know about the project and expected results. In Gilgit-Baltistan, the project requirements were planned without any formal appraisal phase. The projects' triple line expectations were prepared simply on assumptions rather than perceiving the technical, socio-economic, financial, political, and environmental components of the appraisal. Beside this, backup plans and requirements to handle potential problems and challenges, which might occur during the development phases, were not considered in the assessment process. As a result, the projects were not envisaged in a thorough manner in the early stages of the project's conceptualization. Ambiguities in the appraisal process have caused irregularities, thus, capturing incorrect information, decision-making biases, and improper engineering designs. A practical example of this indiscretion in the technical appraisal process is the proper survey of the project sites and the subsequent selection for starting-up the actual work. Due to this, projects had missed their implementation schedules and completion deadlines because of the wrong site selection, which caused an escalation in the project cost, and ultimately, a revision of the scope of the work.

\subsection{Stakeholder Engagement}

Projects excel in achieving their designated objectives when the external stakeholders are engaged wisely and their interests are streamlined in a productive manner. In Gilgit-Baltistan, the affiliation and concern of the external stakeholders (i.e., political and tribal leadership, ethnic groups, along with the local community) remained problematic throughout the phase of implementation. They had not been acknowledged or supported during the development schemes at any point of time and were even irrationally criticized for their vested interests, resulting in deceleration of the physical progress, although their involvement in the decision-making and problem-solving would have improved the delivery of the projects. Ignoring this underlying fact, the executing agency has not made any preventive measures or reviews for resolving these issues and ensuring the completion of dead or slow-moving schemes in a timely manner. This phenomenon has become more chronic during the last decade, and unexpectedly, it has not been addressed by the provisional government either, thus articulating a lack of commitment and participation by all of the external stakeholders.

\subsection{Decision-Making}

The process of decision-making is helpful as it permits analysis and the combination of a unilateral objective with many alternatives. It encompasses the evaluation criteria and corresponding weight of every alternative for a meaningful output. In addition to this, it also makes it possible for the decision makers to compromise or make tradeoffs among the different available options. Hence, the quality of judgment is consequently improved. There is a consensus among the experts that a well-defined decision-making process is paramount for governance. It is important to understand the dynamics of local politics and groups for effective decision-making. In the projects of Gilgit-Baltistan, it was observed that policy decisions were made by people who lacked the subject matter expertise. The decisions were made without considering and identifying alternatives, and expert advice was never solicited during the course of the decision-making. As an example, in many cases it was observed that budgeting decisions were based on insufficient information and analysis. In fact, the expert's role was abandoned during the financial decision-making process, resulting in the cost overrun of projects. In some of the cases, the cost had increased by more than 200 percent because of project revisions.

\subsection{Management Commitment}

The management's commitment during the project life cycle is pertinent to ensure the strategic objectives. Their continual involvement in the decision-making, as well as in problem-solving, tends to improve work processes. Because of this, project teams are expected to be more committed and productive to perform their tasks. In Gilgit-Baltistan, it was observed that the management of the executing agencies had shown a lack of interest and failed to take ownership of their responsibilities. 
They had appointed an incompetent team who had a shortage of skills, experience, and expertise to perform the assigned roles effectively. As a backlash, it has been noted that the progress and payment records were not available, which caused improper verification and monitoring. Failure to maintain the project's financial database resulted in the loss of key information, violation of government regulations, and disrupted the pace of the progress. As an example, it was found that development funds were not utilized as per the schedule of expenditures, which may not only have lapsed, but it would have further reduced the volume of the budget in the future plans. Non-utilization of the funds, failure to maintain the records, and shortcomings in the management commitments eventually impacted on the overall team performance.

\subsection{Political Interference}

In developing countries, political interference is a major hindrance for the smooth execution and delivery of infrastructure development projects. The geopolitical context of Gilgit-Baltistan has greatly influenced the progress of development projects by making it more complicated, slow-moving, and sick, due to political and tribal interferences. The nexus of the elected parliamentary representatives, tribal elites, executing agencies, and contractors were the major cause of nepotism and exploitation. Usually, these intrusions were found during the tendering phase of the projects. In most of the cases, the executing agencies had awarded the contracts on the basis of political affiliations rather than a performance-based system. As a consequence of this embedded corruption and favoritism, the life of the local residents was badly affected by fewer returns on resource use and an increase in their cost of living.

\subsection{Quality Assurance}

The quality assurance and standards are one of the critical success factors of projects. Unfortunately, there was a lack of a proper mechanism for the quality assurance of the development infrastructure projects in Gilgit-Baltistan. In the vagueness of the defined standards, the client, consultant, and contractor had used their own plans and quality standards, which were not compatible with the techno-environmental constraints of the region. The contractors had limited planning capabilities and would generally operate with very basic systems. The quality of projects and project success can be considered as the fulfilment of the expectations of the stakeholders.

\subsection{Human Resource}

Human resource planning is vital and has a tactical importance in project-oriented organizations. Lack of competent human resources has been one of the major constraints compromising the effectiveness of the infrastructure projects in Gilgit-Baltistan. Due to inadequate skills and manpower, there is an increase in the overall cost of the projects, rework, and other multiplier effects during the construction and operational stages. By appointing the right person at the right time in the right place, executing agencies can create a great opportunity to reduce the construction, maintenance, and operational cost. Professionals, whether internal or external, must have the required skill, experience, and no conflicts of interest.

\subsection{Performance Monitoring}

The review of the Gilgit-Baltistan development schemes revealed that the executing agency was not very motivated by the potential benefits of a formal performance monitoring system. Yet, the emphasis on performance measurement greatly contributes to the effective delivery of projects. It can also help organizations involved in public procurement to improve their performances by identifying good practices and cut down the weaknesses in their processes. Performance measurement can also ensure that the organizations are focused on their key priorities and the areas of poor performance are questioned. The processes include collecting, measuring, and distributing performance information, and assessing measurements and trends to effect process improvements. It also gives the project's management team 
insight into the health of the project and identifies any areas that may require special attention. Furthermore, it helps to determine corrective or preventive actions, or re-planning and follow up, to determine if the actions taken resolved the performance issue.

\subsection{Role Ambiguity}

Role ambiguity can be defined as when a member of the team does not have a clear direction of the expectations of their role in the organization. A clear role framework will help the team members to know their job descriptions and the rules of the game before entering into the process. It will also reduce the conflicts that may develop in the lateral stages of the project life cycle. In Gilgit-Baltistan, this phenomenon has turned into non-professional attitudes, misunderstandings, embezzlement, and frequent blunders in performing assigned responsibilities.

\subsection{Legal Disputes}

It is generally recommended that litigation should be avoided and considered as the last option to resolve disputes. The progress of the Gilgit-Baltistan development scheme has tremendously suffered due to legal issues. Physical work had been halted periodically at many occasions, mainly due to site disputes, which resulted in court stay-orders filed by different parties. These disputes led to litigation expenditures and time lapses. A good example was the delay of the approved land compensation scheme in the province. Due to this, landowners had created legal hurdles and demanded the payment of the land reimbursement price on the current enhanced rates. The owners of the land did not allow the executing agency to start groundwork due to partial payments of land compensation, and this led to legal consequences, which further derailed the development process.

\section{Conclusions and Recommendations}

We identified the project governance issues in the regional context of Gilgit-Baltistan. Our analysis suggests that the existing condition of public sector development projects is a matter of concern for the governing and implementing bodies of Gilgit-Baltistan, as they are not very comparable to the performance of the other administrative units of Pakistan. The region is a typical example of misdirected public investment in infrastructure development projects (Haider et al. 2014). The poor performance of the infrastructure projects has been attributed to multiple stakeholders, lack of clear project governance structure, organizational structure, timelines, and communication issues with competing interests (Khan et al. 2018). The root causes of these issues are the weak political and economic conditions of the region (Waris et al. 2017).

This northern region of Pakistan has an emerging geo-political and socio-economic importance in China's "One Belt, One Road" (OBOR) infrastructure corridor. Therefore, as a main governing body, the Planning Works Department of Gilgit-Baltistan need to take the appropriate actions to overcome the ambiguities in the existing planning measures and come up with a stringent approach to ensure a more transparent and efficient project governance system. In this regard, the holistic view of the existing governance issues in policy and planning will provide a sound basis for exploring the enablers of project governance in this provincial administrative setup. As a preliminary step, a mechanism of project governance is necessary to set the vision, project priorities, planning configuration, decision-making, and for defining the roles and responsibilities of all the stakeholders. This will be helpful in developing an organizational structure to support benefit management and resolve conflicts, which are quite common in this multi-ethnic region. This mechanism will also provide the representation of both minority and majority viewpoints and ensure it is widely accepted and establishes the legitimacy of the decisions.

The foremost recommendation of this study is that the public sector infrastructure development projects should invest and adopt a project governance framework to achieve its goals and success. Keeping this in mind, and to broaden the understanding of project governance, more pragmatic research is envisaged in public sector organizations to have a deeper insight into management practices. The project administrative department of the government has to establish a reliable, independent, 
and comprehensive planning strategy with a clear vision and commitment for the successful completion of future projects.

Author Contributions: M.W. and A.K. formulated the study design. A.K. and I.I. conceived and designed the research methodology. A.K., M.W., F.U., M.U. and M.R.S. collected and analyzed the data; M.W. and A.K. wrote the paper.

Funding: The authors would like to acknowledge the financial support by Universiti Malaysia Pahang under the internal grant RDU170312 for this research work.

Acknowledgments: The authors are thankful to all the professionals of the Planning and Development departments, Gilgit-Baltistan, Pakistan for their valuable inputs in this research endeavor.

Conflicts of Interest: The authors declare no conflict of interest.

\section{Appendix A}

Table A1. Sector wise distribution of projects.

\begin{tabular}{lll}
\hline Sector-Wise Projects & No. of Projects & Cost (PKR) Million \\
\hline $\begin{array}{l}\text { Housing } \\
\text { - Residential accommodations }\end{array}$ & 12 & 713 \\
\hline $\begin{array}{l}\text { Water and Power } \\
\text { - Hydel power projects }\end{array}$ & 22 & 2806
\end{tabular}

Natural resource management

- Construction of road for promotion of horticulture

- Construction of play grounds 9

312

- Establishment of tourist information office

Education

- Construction of schools and colleges

- Upgradation of the existing facilities in schools

Health

- Construction and upgradation of hospitals

Transport and Communication

- Construction, metaling and widening of roads

Rural and Urban Development

- Construction of town hall and vocational center

- Provision of clean drinking water facility

\begin{tabular}{lll}
\hline Total & 126 & 6959 \\
\hline
\end{tabular}

The above Table A1 shows the summary of the public sector infrastructure projects in Gilgit-Baltistan. The projects were taken from different sectors, which included housing, water and power, natural resource management, education, health, transportation, and rural development. The total costs of the projects were estimated at PKR 6959.00 million (66 million USD, approximately). These projects had a significant influence on the inhabitants, and the projects' progress had been communicated broadly to the public, which enabled an in-depth document-based study. Three main partners, i.e., 
Planning and Development Department, Public Works Department, and Contractors, had been involved in these projects.

\section{References}

Abednego, Martinus P., and Stephen O. Ogunlana. 2006. Good project governance for proper risk allocation in public-private partnerships in Indonesia. International Journal of Project Management 24: 622-34. [CrossRef]

Ahmed, Riaz M., and Noor Azmi bin Mohamad. 2014. Performance of project in public sector of pakistan: Developing a Framework for future Challenges. Serbian Project Management Journal 4: 3-12.

Ahola, Tuomas, Inkeri Ruuska, Karlos Artto, and Jaakko Kujala. 2014. What is project governance and what are its origins? International Journal of Project Management 32: 1321-32. [CrossRef]

Azhar, Nida, Rizwan U. Farooqui, and Syed M. Ahmed. 2008. Cost overrun factors in construction industry of Pakistan. Paper presented at First International Conference on Construction in Developing Countries (ICCIDC-I), Advancing and Integrating Construction Education, Karachi, Pakistan, August 4-5.

Bekker, Michiel C. 2015. Project Governance-the definition and leadership dilemma. Procedia-Social and Behavioral Sciences 194: 33-43. [CrossRef]

Bekker, Michiel Christiaan, and Herman Steyn. 2007. Defining 'project governance'for large capital projects. Paper presented at AFRICON 2007, Windhoek, South Africa, September 26-28.

Brunet, Maude, and Monique Aubry. 2016. The three dimensions of a governance framework for major public projects. International Journal of Project Management 34: 1596-607. [CrossRef]

Burki, Shahid Javed. 2015. Historical dictionary of Pakistan. Lanham: Rowman \& Littlefield.

Cardenas, Ibsen Chivata, Hans Voordijk, and Geert Dewulf. 2017. Beyond theory: Towards a probabilistic causation model to support project governance in infrastructure projects. International Journal of Project Management 35: 432-50. [CrossRef]

Flyvbjerg, Bent, Nils Bruzelius, and Werner Rothengatter. 2003. Megaprojects and Risk: An Anatomy of Ambition. Cambridge: Cambridge University Press.

Garland, Ross. 2009. Project Governance: A Practical Guide to Effective Project Decision Making. London: Kogan Page Publishers.

Garvin, Michael J. 2009. Governance of PPP projects through contract provisions. Paper presented at Conference of Leadership and Management of Construction, Blacksburg, VA, USA, January 1.

Grant, Maria J., and Andrew Booth. 2009. A typology of reviews: An analysis of 14 review types and associated methodologies. Health Information \& Libraries Journal 26: 91-108.

Guo, Feng, Yan Chang-Richards, Suzanne Wilkinson, and Ti Cun Li. 2014. Effects of project governance structures on the management of risks in major infrastructure projects: A comparative analysis. International Journal of Project Management 32: 815-26. [CrossRef]

Haider, Sajad, Farman Karim, and Mir Nazeem. 2014. Monitoring Report of Development Projects. Skardu, Pakistan: Gilgit-Baltistan.

Hellström, Magnus, Inkeri Ruuska, Kim Wikström, and Daniel Jåfs. 2013. Project governance and path creation in the early stages of Finnish nuclear power projects. International Journal of Project Management 31: 712-23. [CrossRef]

Hjelmbrekke, Hallgrim, Ole Jonny Klakegg, and Jardar Lohne. 2017. Governing value creation in construction project: A new model. International Journal of Managing Projects in Business 10: 60-83. [CrossRef]

Irfan, Muhammad, and Mazlan Hassan. 2017. The Effect of Project Success on Corporate Reputation of the Public Sector Organizations in Pakistan. International Journal of Economics and Management 11: 815-32.

Jonny Klakegg, Ole. 2009. Pursuing relevance and sustainability: Improvement strategies for major public projects. International Journal of Managing Projects in Business 2: 499-518. [CrossRef]

Kanyane, Modimowabarwa Hendrick, and Kombi Sausi. 2015. Reviewing state-owned entities' governance landscape in South Africa. African Journal of Business Ethics 9: 28-42. [CrossRef]

Kazim, Muhammad, Rukhsana Perveen, Abid Zaidi, Rafiq Hussain, Nadia Fatima, and Sherzad Ali. 2015. Biodiversity of spiders (Arachnida: Araneae) fauna of Gilgit Baltistan Pakistan. International Journal of Fauna and Biological Studies 2: 77-79. 
Khan, Asadullah, Ammar Hussain, Muhammad Waris, Ishak Ismail, and Muhammad Ilyas. 2018. Infrastructure project governance: An analysis of public sector project in northern Pakistan. Journal of Governance and Integrity 1: 120-34.

Khattak, Muhammad Sajid, Usman Mustafa, and S. M. Shah. 2016. Mapping Project Management Competencies with Different Complexities for Improving Performance. Journal of Managerial Sciences 10: 206-17.

Klakegg, Ole Jonny, Terry Williams, and Ole Morten Magnussen. 2007. Design of innovative government frameworks for major public investment projects: A comparative study of governance frameworks in UK and Norway. Paper presented at the IRNOP VIII Project Research Conference, September 19-21.

Kochhar, Rahul. 1996. Explaining firm capital structure: The role of agency theory vs. transaction cost economics. Strategic Management Journal 17: 713-28. [CrossRef]

Levitt, Raymond E., Witold J. Henisz, and Daniel Settel. 2009a. Defining and mitigating the governance challenges of infrastructure project development and delivery. Paper presented at 2009 Conference on Leadership and Management of Construction, Lake Tahoe, CA, USA, November 5-8.

Levitt, Raymond E., Witold J. Henisz, and Daniel Settel. 2009b. Defining and mitigating the governance challenges of infrastructure project development and delivery. Paper presented at Conference on Leadership and Management of Construction, Lake Tahoe, CA, USA, November 5-8.

Lizarralde, G., C. Davidson, M. De Blois, and A. Pukteris. 2008. Building Abroad: Procurement of Construction and Reconstruction Projects in the International Context. Montreal: Building Abroad.

Macheridis, Nikos. 2017. Governance of higher education-implementation of project governance. Tertiary Education and Management 23: 85-102. [CrossRef]

McGrath, Stephen Keith, and Stephen Jonathan Whitty. 2015. Redefining governance: From confusion to certainty and clarity. International Journal of Managing Projects in Business 8: 755-87. [CrossRef]

Meso, Peter, Pratim Datta, and Victor Mbarika. 2006. Moderating information and communication technologies' influences on socioeconomic development with good governance: A study of the developing countries. Journal of the American Society for Information Science and Technology 57: 186-97. [CrossRef]

Meso, Peter, Philip Musa, Detmar Straub, and Victor Mbarika. 2009. Information infrastructure, governance, and socio-economic development in developing countries. European Journal of Information Systems 18: 52-65. [CrossRef]

Miller, Roger, and Serghei Floricel. 2000. Building governability into project structures. In The Strategic Management of Large Engineering Projects. Cambridge: MIT Press.

Müller, Ralf, Li Zhai, and Anyu Wang. 2017. Governance and governmentality in projects: Profiles and relationships with success. International Journal of Project Management 35: 378-92. [CrossRef]

Narayanan, V. K., and Robert DeFillippi. 2012. The influence of strategic context on project management systems: A senior management perspective. In Project Governance. Berlin: Springer, pp. 3-45.

Noor, Muhammad Ali, Malik MA Khalfan, and Tayyab Maqsood. 2012. Methods used to procure infrastructure projects in Pakistan: An overview. International Journal of Procurement Management 5: 733-52. [CrossRef]

Noor, Muhammad Ali, Malik M. A. Khalfan, and Tayyab Maqsood. 2013. The role of procurement practices in effective implementation of infrastructure projects in Pakistan. International Journal of Managing Projects in Business 6: 802-26. [CrossRef]

Ogunlana, Stephen O. 2010. Beyond the 'iron triangle': Stakeholder perception of key performance indicators (KPIs) for large-scale public sector development projects. International Journal of Project Management 28: 228-36.

Patanakul, Peerasit, Young Hoon Kwak, Ofer Zwikael, and Min Liu. 2016. What impacts the performance of large-scale government projects? International Journal of Project Management 34: 452-66. [CrossRef]

PC. 2010. Manual for Development Projects; Edited by Planning Commission of Pakistan. Islamabad: Planning Commission.

Pinto, Jeffrey K. 2014. Project management, governance, and the normalization of deviance. International Journal of Project Management 32: 376-87. [CrossRef]

PMI. 2013. A Guide to the Project Management Body of Knowledge: PMBOK Guide, 5th ed. Newton Square: Project Management Institute.

PMI. 2016. Governance of Portfolios, Programs, and Projects: A Practice Guide. Newtown Square: Project Management Institute. 
Reside, Renato E., and Amado M Mendoza. 2010. Determinants of Outcomes of Public-Private Partnerships (PPP) in Infrastructure in Asia. Discussion paper. Quezon City: School of Economics, University of the Philippines Diliman.

Rhodes, Roderick Arthur William. 1996. The new governance: Governing without government. Political Studies 44: 652-67. [CrossRef]

Rowley, Jennifer. 2002. Using case studies in research. Management Research News 25: 16-27. [CrossRef]

Schroeder, Andreas, David Pauleen, and Sid Huff. 2012. KM governance: The mechanisms for guiding and controlling KM programs. Journal of Knowledge Management 16: 3-21. [CrossRef]

Sharma, Chandan. 2012. Determinants of PPP in infrastructure in developing economies. Transforming Government: People, Process and Policy 6: 149-66. [CrossRef]

Stoker, Gerry. 1998. Governance as theory: Five propositions. International Social Science Journal 50: 17-28. [CrossRef]

Too, Eric G., and Patrick Weaver. 2014. The management of project management: A conceptual framework for project governance. International Journal of Project Management 32: 1382-94. [CrossRef]

Unab, Wafa, and Muhammad Faheem A. Kundi. 2014. Review of project management (PM) practices in public infrastructure development organizations of Pakistan. Journal of Strategy and Performance Management 2: 144.

Vaismoradi, Mojtaba, Hannele Turunen, and Terese Bondas. 2013. Content analysis and thematic analysis: Implications for conducting a qualitative descriptive study. Nursing $\mathcal{E}$ Health Sciences 15: 398-405.

Waris, M., Khan Asadullah, Ismail Ishak, and Sitansu Panda. 2017. Project governance: A need for public sector infrastructure projects in Pakistan. Paper presented at FGIC 1st Conference on Governance \& Integrity, "Innovation \& Sustainability Through Governance" Yayasan Pahang, Kuantan, Malaysia, April 3-4.

Williamson, Oliver E. 1979. Transaction-cost economics: The governance of contractual relations. The Journal of Law and Economics 22: 233-61. [CrossRef]

Winch, Graham M. 2001. Governing the project process: A conceptual framework. Construction Management $\mathcal{E}$ Economics 19: 799-808.

World Bank. 2017. Social Analysis: Glossary of Key Terms. Available online: http://go.worldbank.org/ HSXB13LCA0 (accessed on 5 June 2018).

Xiang, Wenwen, Ying Li, and Yongyi Shou. 2013. An empirical study of critical success factors of project governance in China. Paper presented at 2013 IEEE International Conference on Industrial Engineering and Engineering Management (IEEM), Bangkok, Thailand, December 10-13.

Xie, Lin-lin, Yu Yang, Yi Hu, and Albert P. C. Chan. 2014. Understanding project stakeholders' perceptions of public participation in China's infrastructure and construction projects: Social effects, benefits, forms, and barriers. Engineering, Construction and Architectural Management 21: 224-40. [CrossRef]

Yin, Robert K. 2017. Case Study Research and Applications: Design and Methods. Thousand Oaks: Sage Publications.

Zhai, Li, Yanfei Xin, and Chaosheng Cheng. 2009. Understanding the value of project management from a stakeholder's perspective: Case study of mega-project management. Project Management Journal 40: 99-109. [CrossRef]

Zhai, Zhao, Tuomas Ahola, Yun Le, and Jianxun Xie. 2017. Governmental governance of megaprojects: The case of EXPO 2010 Shanghai. Project Management Journal 48: 37-50. [CrossRef]

Zwikael, Ofer, and John Smyrk. 2015. Project governance: Balancing control and trust in dealing with risk. International Journal of Project Management 33: 852-62. [CrossRef]

(C) 2019 by the authors. Licensee MDPI, Basel, Switzerland. This article is an open access article distributed under the terms and conditions of the Creative Commons Attribution (CC BY) license (http://creativecommons.org/licenses/by/4.0/). 